\title{
Persistence of Anti-SARS-CoV-2 Antibodies Six Months after Infection in an Outbreak with Five Hundred COVID-19 Cases in Borriana (Spain): A Prospective Cohort Study
}

\author{
Salvador Domènech-Montoliu ${ }^{1}$, Joan Puig-Barberà ${ }^{2}\left(\mathbb{D}\right.$, Maria Rosario Pac-Sa ${ }^{3}$, Paula Vidal-Utrillas ${ }^{4}$, \\ Marta Latorre-Poveda ${ }^{1}$, Alba Del Rio-González ${ }^{4}$, Sara Ferrando-Rubert ${ }^{4}$, Gema Ferrer-Abad ${ }^{4}$, \\ Manuel Sánchez-Urbano ${ }^{1}$, Laura Aparisi-Esteve ${ }^{5}{ }^{\circledR}$, Gema Badenes-Marques ${ }^{1}$, Belén Cervera-Ferrer ${ }^{1}$, \\ Ursula Clerig-Arnau ${ }^{1}$, Claudia Dols-Bernad ${ }^{6}$, Maria Fontal-Carcel ${ }^{7}$, Lorna Gomez-Lanas ${ }^{1}$, David Jovani-Sales ${ }^{5}{ }^{\mathbb{C}}$, \\ Maria Carmen León-Domingo ${ }^{8}$, Maria Dolores Llopico-Vilanova ${ }^{1}$, Mercedes Moros-Blasco ${ }^{5}$, \\ Cristina Notari-Rodríguez ${ }^{1}$, Raquel Ruíz-Puig ${ }^{1}$, Sonia Valls-López ${ }^{1}$ and Alberto Arnedo-Pena ${ }^{3,9,10, *}$
}

check for updates

Citation: Domènech-Montoliu, S.; Puig-Barberà, J.; Pac-Sa, M.R.;

Vidal-Utrillas, P.; Latorre-Poveda, M.; Del Rio-González, A.;

Ferrando-Rubert, S.; Ferrer-Abad, G.; Sánchez-Urbano, M.; Aparisi-Esteve,

L.; et al. Persistence of

Anti-SARS-CoV-2 Antibodies Six

Months after Infection in an Outbreak with Five Hundred COVID-19 Cases in Borriana (Spain): A Prospective Cohort Study. COVID 2021, 1, 71-82. https://doi.org/10.3390/covid1010006

Academic Editor: Stefano Aquaro

Received: 3 June 2021

Accepted: 25 June 2021

Published: 30 June 2021

Publisher's Note: MDPI stays neutral with regard to jurisdictional claims in published maps and institutional affiliations.

Copyright: (c) 2021 by the authors. Licensee MDPI, Basel, Switzerland. This article is an open access article distributed under the terms and conditions of the Creative Commons Attribution (CC BY) license (https:/ / creativecommons.org/licenses/by/ $4.0 /)$.
1 Emergency Service Hospital de la Plana, 12540 Vila-real, Spain; domenech_salmon@gva.es (S.D.-M.); martalapo@hotmail.com (M.L.-P.); manu.msu@gmail.com (M.S.-U.); gemabamar@hotmail.com (G.B.-M.); belencerveraferrer@hotmail.com (B.C.-F.); ursuclerig@gmail.com (U.C.-A.); lornagl78@gmail.com (L.G.-L.); llopivila@hotmail.com (M.D.L.-V.); notari_cri@gva.es (C.N.-R.); raquelruizpuig@gmail.com (R.R.-P.); Sonia.valls.lopez@gmail.com (S.V.-L.)

2 Vaccines Research Area FISABIO, 46020 Valencia, Spain; jpuigb55@gmail.com

3 Public Health Center, 12540 Castelló de la Plana, Spain; charopac@gmail.com

4 Health Centers I and II, 12540 Borriana, Spain; vidalutrillaspaula@gmail.com (P.V.-U.); delrio_alb@gva.es (A.D.R.-G.); sfr1812@gmail.com (S.F.-R.); gferrer@uji.es (G.F.-A.)

5 Carinyena Health Center, 12540 Vila-real, Spain; lauraaparisiesteve@gmail.com (L.A.-E.); jovasal1987@gmail.com (D.J.-S.); mercedesmb1094@hotmail.com (M.M.-B.)

6 Health Center, 12540 Onda, Spain; claudiadb1294@hotmail.com

7 Health Center, 12540 La Vall d'Uixó, Spain; fontalcarce193@hotmail.com

Villa Fátima School, 12540 Borriana, Spain; carmendole@hotmail.com

9 Department of Health Science, Public University Navarra, 31006 Pamplona, Spain

10 Epidemiology and Public Health (CIBERESP), 28029 Madrid, Spain

* Correspondence: arnedo_alb@gva.es or albertoarnedopena@gmail.com; Tel.: +35-622-573979

Abstract: In March 2020, several mass gathering events were related to the Falles festival in Borriana (Spain), resulting in a 536 laboratory-confirmed COVID-19 cases outbreak among participants. This article estimates anti-SARS-CoV-2 antibodies persistence six months after and factors associated with antibody response. A prospective population-based cohort study was carried out by the Public Health Centre of Castellon and the Emergency and Clinical Analysis and Microbiology Services of Hospital de la Plana in Vila-real. In October 2020, a seroepidemiologic study was used to estimate the persistence of anti-SARS-CoV-2 antibodies against nucleocapsid protein $(\mathrm{N})$ by an electrochemiluminescence immunoassay (ECLIA) was implemented. We enrolled $484(90.2 \%)$ of the 536 members of the initial outbreak cohort and detected persistent antibodies in 479 (99\%) without reinfection episodes. Five participants had a negative antibody test. Factors associated with a negative result were a lower body mass index (BMI), and less contact with other COVID-19 cases. Among the 469 participants with two ECLIA tests, 96 (20.5\%) had an increase of antibodies and 373 $(79.5 \%)$ a decline. Increased antibodies were associated with older age, higher BMI, more severe illness, and low current smokers. Our results show that after a COVID-19 infection, a high proportion of cases maintain detectable anti-SARS-CoV-2 antibodies.

Keywords: SARS-CoV-2; COVID-19; antibodies; cohort; population-based; body mass index; ECLIA

\section{Introduction}

At the time of writing, severe acute respiratory syndrome coronavirus 2 (SARS-CoV-2) has caused 160,457,476 confirmed cases and 3,331,604 deaths globally [1]. One of the 
main unknowns is the duration of immunity elicited after coronavirus disease (COVID-19) in recovered patients. Other aspects of interest are the protection against SARS-CoV-2 reinfection, and factors related to developing persistent SARS-Cov-2 immunity. Serologic surveys are needed to gather evidence on the persistence and protection of the humoral immunity to SARS-CoV-2 infection [2,3], as well as the study of the cellular immunity mediated by $\mathrm{T}$ cells $[4,5]$.

In the first days of March 2020, several mass gathering events (MGEs) for the Falles festival took place in Borriana, a city of 35,000 inhabitants in Castellon (Spain), and a COVID-19 outbreak ensued. During March-June 2020, an epidemiologic study whit a serologic survey of this outbreak found 570 COVID-19 cases (536 laboratory-confirmed and 34 with clinical and epidemiologic criteria), 13 admissions and one death, among 1338 participants in the MGEs; the attack rate (AR) was $42.6 \%$.

The follow-up of a representative sample of the COVID-19 cases through a serologic survey to determine SARS-CoV-2 antibodies would offer the opportunity to know the duration of immunity after COVID-19. Accordingly, our objective was to conduct a seroepidemiological study, six months after the first study, to estimate the persistence of antiSARS-CoV-2 antibodies among MGEs participants who suffered a laboratory-confirmed COVID-19 infection and the potential factors associated with the persistence and intensity of the immune response.

\section{Materials and Methods}

The study, a prospective population-base cohort study, was carried out by the Public Health Centre of Castellon and the Emergency and Clinical Analysis and Microbiology Services of Hospital de la Plana in Vila-real. We invited all the subjects who tested positive for SARS-CoV-2 in the outbreak of the MGEs of Falles festival to participate in a second seroepidemiological study in October 2020.

The tests used to ascertain SARS-CoV-2 infection in the first study were: Qualitative Electrochemiluminescence immunoassay (ECLIA) (Elecsys ${ }^{\circledR}$ Anti-SARS-CoV-2, Roche Diagnostics) [6], in 514 subjects. Lateral flow immunochromatographic assay (LFIC) (Healgen Scientific LLC for COVID-19 IgG/IgM rapid test cassette [7], in 15 subjects. Reversetranscriptase polymerase chain reaction (RT-PCR), including LightMix ${ }^{\circledR}$ Modular Sarbecovirus E-gene with the LightCycler ${ }^{\circledR} 480$ II system [8], in 39 subjects. In 32 subjects, we obtained both ECLIA and PCR results.

The outbreak cohort members with a laboratory-confirmed COVID-19 test were 536 cases from the first serologic survey between March and June 2020. The second serologic survey to determine anti-SARS-CoV-2 antibodies by ECLIA was implemented during October 2020, and 484 of the 536 members of the cohort took part (90.3\%). Overall, 469 members had two ECLIA determinations after the second serologic survey (Figure 1).

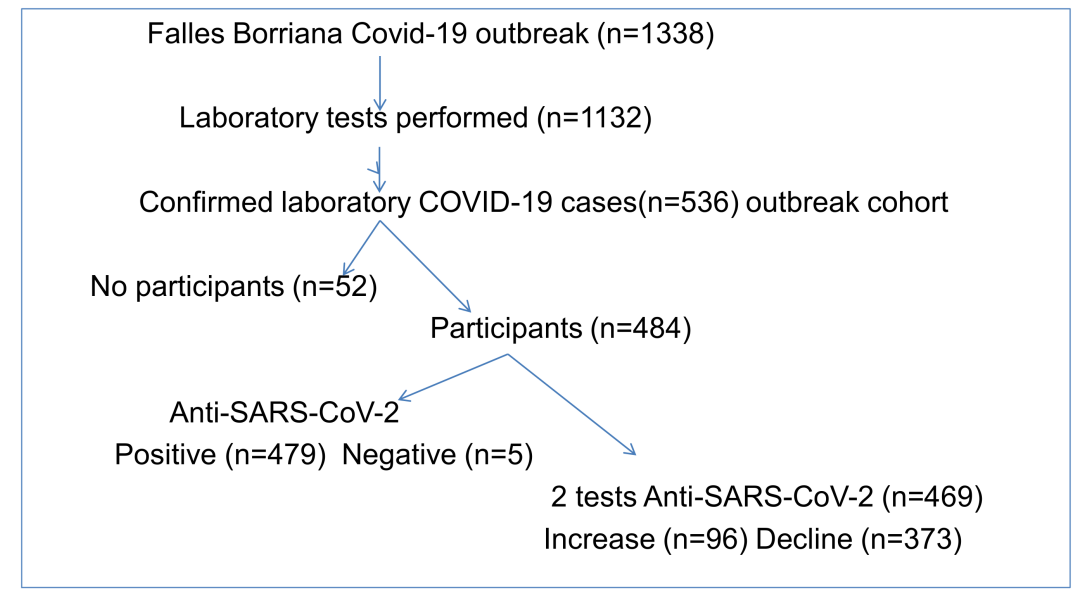

Figure 1. Flow chart of Borriana COVID-19 outbreak cohort. 
The ECLIA test, already described above, uses a modified double-antigen sandwich immunoassay using recombinant SARS-CoV-2 nucleocapsid protein (N) [6]. The test results are reported as numeric values, considering a reactive cutoff index $(\mathrm{COI})>1.0$ as a positive result and a COI $<0.1$ as a negative result.

We explore factors associated with the immune response, comparing the geometric mean of total anti-SARS-CoV-2 antibodies of participants in the first and second serologic surveys and the change in magnitude between tests as an increase or a decline. The first blood samples were not available for a simultaneous analysis with the second samples. We also explored the potential associations [9-12] with COVID-19 of ABO blood groups, ascertained by the gel test (ID-Card ABO/RhD, DiaMed GmbH, Bio-Rad Laboratories Switzerland) [13] and 25-hydroxy vitamin D [25(OH)D] levels, determined by electrochemiluminisence-based assay (Elecsys vitamin D total II Roche Diagnostic, Germany) [14].

Health staff of the Hospital de la Plana, and the health centres of Borriana, Vila-real, Onda, and La Vall d'Uixo conducted a telephone questionnaire survey in October 2020, asking the participants about their health situation, the occurrence of disease in the last six months, medical assistance, evolution of COVID-19 disease, sequelae, SARS-CoV-2 reinfections, and subsequent exposures. We obtained information about other potential factors associated with the immune response, such as age, sex, weight, height, body mass index (BMI) $\left(\mathrm{kg} / \mathrm{m}^{2}\right)$, occupation, level of physical exercise, smoking habits, consumption of alcohol, chronic illness and COVID-19 exposures, either in the household or in other settings from the questionnaire survey during May-June 2020.

\section{Statistical Analysis}

We used the Chi2 test and Fisher exact test for qualitative variables, Kruskal-Wallis test for quantitative variables, and Wilcoxon matched-pairs signed-rank test and equality of median for matched pairs test to compare the changes in anti-SARS-CoV-2 antibodies between the two serologic surveys. Positive or negative detection of anti-SARS-CoV2 antibodies in the second respect to the first survey was the dependent variable. We estimated the associations between this variable and several factors by relative risks (RR) through univariate and multivariate (adjusted RR) Poisson regression, robust or exact according to models' conditions, with 95\% confidence intervals (CI). Besides, we analysed the increase and decline in anti-SARS-CoV-2 antibody arbitrary units following the same statistical approach. As Vitamin D was only measured in the second serologic survey, we did not include it in multivariate models. After a review of SARS-CoV-2 medical literature, we studied the potential confounding factors by Directed Acyclic Graphs (DAGs) [15] using the DAGitti 3.0 program [16]. With a sample size of 454 cohort members, the study had a power of $80 \%$ and alpha error of $5 \%$ to detect at least a $2 \%$ change in the fraction of positives between the first and second serologic surveys. We used Stata ${ }^{\circledR}$ version 14 statistical program for all calculations and estimates.

The following of the study's cohort was a part of the public health surveillance as a prolongation of the COVID-19 outbreak control measures, and the response of the COVID19 pandemic. It was exempt from the Ethics Review Board approval's protocol according to the Spanish legislation. The study was approved by the director of the Public Health Center of Castellon and the management of the Health Department of la Plana. All participants or the parents of minors provided the informed written consent to be included in the study.

\section{Results}

A total of 484 (90.2\%) of 536 subjects accepted to participate (Figure 1) (Table 1). We did not observe significant differences between participants and no-participants, except for MGEs assistance, which was lower in non-participants $(p<0.001)$.

From 484 participants in the outbreak cohort, persistent antibodies were detected in 479 (99\%), and reinfection episodes were detected. Only five of the 484 participants (1.0\%) had a negative anti-SARS-CoV-2 antibody in the second determination. 
Table 1. Participants and non-participants characteristics. COVID-19 Borriana cohort second SARS-CoV-2 serologic survey, October 2020.

\begin{tabular}{|c|c|c|c|}
\hline Variables & $\begin{array}{l}\text { Participant } \\
\mathrm{N}=484(\%)\end{array}$ & $\begin{array}{l}\text { No-Participants } \\
\mathrm{N}=52(\%)\end{array}$ & $p$-Value \\
\hline Female & $301(62.2)$ & $32(61.5)$ & 1.000 \\
\hline Age mean \pm Standard Deviation & $37.2 \pm 17.1$ & $33.5 \pm 16.7$ & 0.064 \\
\hline $0-24$ years & $143(29.5)$ & $19(36.5)$ & \multirow{4}{*}{0.483} \\
\hline $25-44$ & $157(32.4)$ & $17(32.7)$ & \\
\hline $45-64$ & $166(34.3)$ & $16(30.8)$ & \\
\hline 65 and over & $18(3.7)$ & $0(0.0)$ & \\
\hline \multicolumn{4}{|l|}{ Body mass index ${ }^{1} \mathrm{Kg} / \mathrm{m}^{2}$} \\
\hline$<18.0$ & $41(8.5)$ & $6(11.5)$ & \multirow{4}{*}{0.747} \\
\hline $18.0-24.9$ & $210(43.7)$ & $24(46.2)$ & \\
\hline $25.0-29.9$ & $148(30.8)$ & $13(25.0)$ & \\
\hline$\geq 30.0$ & $85(17.7)$ & $9(17.3)$ & \\
\hline Occupation I-II 2,3 & $145(30.1)$ & $16(30.7)$ & 1.000 \\
\hline Current smoker 4 & $65(13.9)$ & $12(23.1)$ & 0.221 \\
\hline Physical exercise & $389(80.4)$ & $24(46.2)$ & 0.075 \\
\hline Alcohol beverages 5 & $108(23.0)$ & $10(19.2)$ & 0.604 \\
\hline Chronic illness 6 & $166(34.6)$ & $14(26.9)$ & 0.285 \\
\hline \multicolumn{4}{|l|}{ COVID-19 } \\
\hline Family with COVD-19 case $^{7}$ & $303(62.7)$ & $31(59.6)$ & 0.554 \\
\hline Probable contact COVID-19 case ${ }^{8}$ & $390(81.8)$ & $39(75.0)$ & 0.349 \\
\hline Assistance Mass Gathering events $\geq 2$ and over ${ }^{9}$ & $295(61.0)$ & $16(30.8)$ & 0.000 \\
\hline Hospitalisations & $9(1.9)$ & $3(5.8)$ & 0.101 \\
\hline PCR positive & $26(5.4)$ & $13(25.0)$ & $\mathrm{NC}^{10}$ \\
\hline Asymptomatic & $54(11.2)$ & $10(19.2)$ & 0.111 \\
\hline Medical consultation & $208(43.0)$ & $25(48.1)$ & 0.556 \\
\hline
\end{tabular}

${ }^{1}$ Missing information for 3 participants; ${ }^{2}$ Occupation groups I-II: Professional, managerial and technical occupations. Groups III-VI: Skilled, non-manual or manual, partly-skilled, unskilled occupations; ${ }^{3}$ Missing information for 3 participants; ${ }^{4}$ Missing information for 16 participants; ${ }^{5}$ Missing information for 14 participants; ${ }^{6}$ Missing information for 4 participants; ${ }^{7}$ Missing information for 1 participant; ${ }^{8}$ Missing information for 7 participants; ${ }^{9}$ Excluding participants with COVID-19 symptoms before 6 March or after 31 March 2020; 10 No calculable only positive PCR cases recorded.

A non-adjusted comparison of subjects with a negative and a positive ECLIA is presented in Table 2. Negative ECLIA subjects were younger with a lower BMI and reported lower frequency of probably contacts with COVID-19 cases and MGEs attendance; shorter duration, no medical consultations, and full recovery COVID-19 disease. In contrast, one-third of the ECLIA positive subjects suffered some sequelae, not recovered completely and had a worse health level than before the COVID-19 disease. The ECLIA results did not differ by the $\mathrm{O}$ positive, $\mathrm{ABO}$ blood group, or vitamin $\mathrm{D}$ mean serum concentration.

We show in Table 3 the multivariate Poisson regression adjusted relative risk (aRR) of the association between the measured factors and an ECLIA negative result. The negative anti-SARS-COV-2 antibody group had a lower BMI (aRR $=0.83$ 95\% CI 0.72-0.99), less probable contact with COVID-19 cases ( $\mathrm{aRR}=0.1395 \% \mathrm{CI} 0.03-0.51)$ and was younger (aRR $=0.9695 \%$ CI 0.91-1.00).

Among the 484 participants, $469(96.7 \%)$ had two anti-SARS-CoV-2 antibody determinations by ECLIA, one in the first study (June 2020) and the second in the current survey. We observed an overall decline in the values of the arbitrary units of the ECLIA test from June 2020, geometric mean 46.41 (95\% CI 41.87-51.44) to October 2020, geometric mean 26.55 (95\% CI $23.30-30.25)(p<0.001)$. However, ninety-six participants $(20.5 \%)$ had an increase of antibodies, whereas 373 participants $(79.5 \%)$ had a decline. The comparison of the two groups is in Table 4. Participants with increased antibodies were older, not current smokers, had a higher BMI, a higher frequency of probable contact with COVID-19 cases, more medical consultation, and a longer duration of the illness. Vitamin D status and O $\mathrm{ABO}$ blood levels were similar in both groups. 
After an adjusted Poisson regression analysis (Table 5), high BMI, older age, a medical consultation and more contact with COVID-19 cases were associated with an increase of anti-SARS-CoV-2 antibodies, being a current smoker was associated with a decline in anti-SARS-CoV-2 antibodies (Figure 2).

Table 2. Subjects' characteristic distribution by SARS-CoV-2 ECLIA result, and unadjusted relative risk of comparing negative versus persistent antibody (positive ECLIA) results. COVID-19 Borriana cohort, second seroepidemiological survey, October 2020.

\begin{tabular}{|c|c|c|c|c|c|}
\hline Variables & $\begin{array}{c}\text { Negative } \\
\text { Antibodies } \\
N=5(\%)\end{array}$ & $\begin{array}{l}\text { Persistent } \\
\text { Antibodies } \\
\mathrm{N}=479(\%)\end{array}$ & $\mathbf{R R}^{1}$ & $95 \% \mathrm{CI}^{2}$ & $p$-Value \\
\hline Female & $4(80.0)$ & $297(62.0)$ & 0.41 & $0.05-3.66$ & 0.426 \\
\hline Age mean \pm standard deviation & $24.0 \pm 16.7$ & $37.4 \pm 17.1$ & 0.95 & $0.90-1.01$ & 0.106 \\
\hline $0-24$ years & $4(80.0)$ & $139(29.0)$ & & & \multirow{4}{*}{0.123} \\
\hline $25-44$ & 0 & $157(32.8)$ & & & \\
\hline $45-64$ & $1(20.0)$ & $165(34.4)$ & & & \\
\hline 65 and over & 0 & $18(3.8)$ & & & \\
\hline $\mathrm{OABO}^{3}$ & $4(80)$ & $195(40.8)$ & 5.71 & $0.64-50.8$ & 0.116 \\
\hline Vitamin D ng/mL & $28.2 \pm 8.9$ & $29.8 \pm 9.2$ & 0.98 & $0.87-1.09$ & 0.687 \\
\hline Body mass index ${ }^{4} \mathrm{Kg} / \mathrm{m}^{2}$ & $21.3 \pm 2.7$ & $25.0 \pm 5.0$ & 0.84 & $0.76-0.94$ & 0.002 \\
\hline$<18.0$ & $1(20.0)$ & $40(8.4)$ & & & \multirow{4}{*}{0.038} \\
\hline $18.0-24.9$ & $4(80.0)$ & $206(43.3)$ & & & \\
\hline $25.0-29.9$ & 0 & $148(31.1)$ & & & \\
\hline$\geq 30.0$ & 0 & $85(17.9)$ & & & \\
\hline Occupation I-II ${ }^{5}$ & $1(20.0)$ & $144(30.3)$ & 0.57 & $0.07-5.15$ & 0.624 \\
\hline Current smoker 6 & $1(20.0)$ & $64(13.8)$ & 1.19 & $0.37-3.82$ & 0.776 \\
\hline Physical exercise & $4(80.0)$ & $285(59.5)$ & 2.70 & $0.30-24.08$ & 0.653 \\
\hline Alcohol consumption ${ }^{7}$ & $1(20.0)$ & $107(23.0)$ & 0.83 & $0.29-7.44$ & 0.874 \\
\hline Chronic illness $^{8}$ & 0 & $166(34.9)$ & 0.28 & $0.00-2.06$ & 0.240 \\
\hline \multicolumn{6}{|l|}{ COVID-19 disease } \\
\hline Family with COVD-1 9 case $^{9}$ & $2(40.0)$ & $301(63.0)$ & 0.39 & $0.07-2.35$ & 0.308 \\
\hline Probable contact COVID-19 case ${ }^{10}$ & $2(40.0)$ & $388(82.2)$ & 0.15 & $0.03-0.88$ & 0.044 \\
\hline Assistance Mass Gathering Events $\geq 2$ and over 11 & $1(25 \%)$ & $255(60.6)$ & 0.22 & $0.02-2.10$ & 0.189 \\
\hline Hospitalisations & 0 & $9(1.9)$ & 7.85 & $0.00-19.23$ & 1.000 \\
\hline PCR positive & 0 & $26(5.4)$ & 2.61 & $0.00-57.60$ & 1.000 \\
\hline Asymptomatic & $1(20.0)$ & $53(11.1)$ & 1.99 & $0.23-17.62$ & 0.448 \\
\hline Medical consultation & 0 & $208(43.4)$ & 0.19 & $0.00-1.45$ & 0.121 \\
\hline Illness duration & $4.3 \pm 6.7$ & $10.4 \pm 17.5$ & 0.93 & $0.76-1.13$ & 0.457 \\
\hline \multicolumn{6}{|l|}{ Post-COVID-19 } \\
\hline Sequelae & 0 & $159(33.2)$ & 0.30 & $0.00-2.23$ & 0.273 \\
\hline Health as before the disease 12 & $5(100.0)$ & $397(83.1)$ & 1.36 & $0.18-\infty$ & 0.732 \\
\hline Recover health 13 & $5(100.0)$ & $390(81.6)$ & 1.50 & $0.20-\infty$ & 0.800 \\
\hline \multicolumn{6}{|l|}{ Exposure post-COVID-19 } \\
\hline Social contact & $4(80.0)$ & $103(78.5)$ & 1.09 & $0.12-9.79$ & 0.935 \\
\hline Gathering people & 0 & $25(5.2)$ & 2.73 & $0.00-20.04$ & 1.000 \\
\hline Trip out of Borriana 14 & $1(20.0)$ & $109(22.9)$ & 0.85 & $0.10-7.50$ & 0.880 \\
\hline Restaurant assistance & 0 & $142(29.6)$ & 0.36 & $0.00-2.63$ & 0.352 \\
\hline Terrace assistance ${ }^{15}$ & $3(60.0)$ & $286(59.8)$ & 2.19 & $0.37-13.04$ & 0.400 \\
\hline
\end{tabular}

${ }^{1} \mathrm{RR}=$ Relative risk; ${ }^{2} \mathrm{CI}=$ Confidence interval; ${ }^{3}$ Missing information for 1 participant; ${ }^{4}$ Missing information for 3 participants; ${ }^{5}$ Missing information for 3 participants; ${ }^{6}$ Missing information for 16 participants; ${ }^{7}$ Missing information for 14 participants; ${ }^{8}$ Missing information for 4 participants; ${ }^{9}$ Missing information for 1 participant; ${ }^{10}$ Missing information for 7 participants; ${ }^{11}$ Excluding participants with COVID-19 symptoms before 6 March or after 31 March 2020; ${ }^{12}$ Missing information for 1 participant; ${ }^{13}$ Missing information for 1 participant; ${ }^{14}$ Missing information for 2 participants; ${ }^{15}$ Missing information for 1 participant. 
Table 3. Adjusted relative risks (aRR) of factors associated with negative anti-SARS-CoV-2 antibody group versus persistent (positive ECLIA result), by Poisson regression. COVID-19 Borriana cohort 2020.

\begin{tabular}{|c|c|c|c|c|}
\hline Factors & aRR & $95 \% \mathrm{CI}^{1}$ & $p$-Value & Pearson Goodness of Fit \\
\hline Body mass index $\left(\mathrm{Kg} / \mathrm{m}^{2}\right)^{2}$ & 0.87 & $0.77-0.99$ & 0.037 & 0.817 \\
\hline Age (years) ${ }^{3}$ & 0.96 & $0.91-1.00$ & 0.076 & 0.971 \\
\hline Sex: Female 4 & 0.59 & $0.09-3.96$ & 0.590 & 0.971 \\
\hline O ABO blood group ${ }^{5}$ & 5.52 & $0.61-49.57$ & 0.127 & 0.971 \\
\hline Occupation I-II 6 & 0.66 & $0.08-5.45$ & 0.695 & 0.587 \\
\hline Current smoker ${ }^{7}$ & 2.43 & $0.14-41.87$ & 0.541 & 0.072 \\
\hline Physical exercise ${ }^{7}$ & 3.05 & $0.36-25.71$ & 0.305 & 0.999 \\
\hline Alcohol consumption ${ }^{7}$ & 1.07 & $0.10-11.77$ & 0.954 & 0.398 \\
\hline Chronic illness ${ }^{8}$ & 0.42 & $0.00-3.35$ & 0.456 & $\mathrm{NC}^{9}$ \\
\hline \multicolumn{5}{|l|}{ COVID-19 disease } \\
\hline Family with COVD-19 case ${ }^{10}$ & 0.49 & $0.08-2.85$ & 0.428 & 0.540 \\
\hline Probable contact COVID-19 case ${ }^{11}$ & 0.18 & $0.04-0.82$ & 0.027 & 1.000 \\
\hline Assistance Mass Gathering Events $\geq 2$ and over ${ }^{12,13}$ & 0.20 & $0.02-1.78$ & 0.150 & 0.458 \\
\hline Medical consultation ${ }^{14}$ & 0.26 & $0.00-2.05$ & 0.227 & $\mathrm{NC}^{9}$ \\
\hline Illness duration ${ }^{15}$ & 0.94 & $0.77-1.15$ & 0.570 & 1.000 \\
\hline
\end{tabular}

${ }^{1} \mathrm{CI}=$ Confidence interval; ${ }^{2}$ Adjusted for age sex $\mathrm{ABO}$, occupation current smoker physical exercise alcohol consumption; ${ }^{3}$ Adjusted for sex ABO; ${ }^{4}$ Adjusted for ABO age; ${ }^{5}$ Adjusted for sex age. ${ }^{6}$ Adjusted for age ABO sex; ${ }^{7}$ Adjusted for age sex ABO occupation; ${ }^{8}$ Adjusted for age sex $\mathrm{ABO}$ current smoker physical exercise alcohol beverage; ${ }^{9} \mathrm{NC}=$ No computable; ${ }^{10}$ Adjusted for age sex $\mathrm{ABO}$ chronic illness current smoker physical exercise alcohol consumption assistance mass gathering events $\geq 2$ and over; ${ }^{11}$ Adjusted for age, sex $A B O$ occupation current smoker physical exercise alcohol consumption assistance mass gathering events $\geq 2$ and over; ${ }^{12}$ Excluding participants with symptoms before 6 March or after 31 March 2020; ${ }^{13}$ Adjusted for age, sex, ABO, occupation, current smoker physical exercise alcohol consumption assistance mass gathering events $\geq 2$ and over; ${ }^{14}$ Adjusted for age sex, ABO, chronic illness occupation. ${ }^{15}$ Adjusted by age, sex, body mass index, $\mathrm{ABO}$, chronic illness.

Table 4. Comparison between participants with increase and decline anti-SARS-CoV-2 antibodies, considering the first and second SARS-CoV-2 serologic surveys. COVID-19 Borriana cohort 2020.

\begin{tabular}{|c|c|c|c|}
\hline Variables & $\begin{array}{c}\text { Increase } \\
\text { SARS-CoV-2 } \\
\text { N = } 96(\%)\end{array}$ & $\begin{array}{c}\text { Decline } \\
\text { SARS-CoV-2 } \\
\text { N = 373 }(\%)\end{array}$ & $p$-Value \\
\hline Female & $60(62.5)$ & $236(63.5)$ & 0.906 \\
\hline Age mean \pm standard deviation & $45.3 \pm 18.0$ & $34.9 \pm 16.3$ & 0.001 \\
\hline $0-24$ years & $15(15.6)$ & $126(33.8)$ & \multirow{4}{*}{0.000} \\
\hline $25-44$ & $24(25.0)$ & $131(35.1)$ & \\
\hline $45-64$ & $47(49.0)$ & $108(29.0)$ & \\
\hline 65 and over & $10(10.4)$ & $8(2.1)$ & \\
\hline $\mathrm{OABO}^{1}$ & $45(46.9)$ & $149(40.1)$ & 0.246 \\
\hline Vitamin D ng/mL & $29.4 \pm 9.0$ & $30.0 \pm 9.3$ & 0.621 \\
\hline Body mass index $\left(\mathrm{Kg} / \mathrm{m}^{2}\right)$ & $26.9 \pm 5.0$ & $24.5 \pm 4.9$ & 0.001 \\
\hline$<18.0$ & $6(6.3)$ & $38(10.2)$ & \multirow{4}{*}{0.001} \\
\hline $18.0-24.9$ & $27(28.1)$ & $176(47.2)$ & \\
\hline $25.0-29.9$ & $35(36.5)$ & $107(28.7)$ & \\
\hline$\geq 30.0$ & $38(40.0)$ & $55(14.7)$ & \\
\hline Occupation I-II ${ }^{2}$ & $29(30.2)$ & $107(28.9)$ & 0.802 \\
\hline Current smoker ${ }^{3}$ & $7(7.5)$ & $56(15.6)$ & 0.003 \\
\hline Physical exercise & $57(59.4)$ & $222(59.5)$ & 1.000 \\
\hline Alcohol beverages ${ }^{4}$ & $24(25.8)$ & $82(22.7)$ & 0.583 \\
\hline Chronic illness ${ }^{5}$ & $41(43.2)$ & $123(45.6)$ & 0.092 \\
\hline COVID-19 & & & \\
\hline Family with COVD-19 case ${ }^{6}$ & $63(65.6)$ & $230(61.8)$ & 0.555 \\
\hline Probable contact COVID-19 case ${ }^{7}$ & $83(89.2)$ & $294(79.7)$ & 0.036 \\
\hline Assistance Mass Gathering Events $\geq 2$ and over ${ }^{8}$ & $61(63.5)$ & $227(60.9)$ & 0.724 \\
\hline Hospitalisations & $3(3.1)$ & $6(1.6)$ & 0.398 \\
\hline PCR positive & $8(8.3)$ & $17(4.6)$ & 0.198 \\
\hline Asymptomatic & $7(7.3)$ & 46 (12.3) & 0.206 \\
\hline Medical consultation & $56(58.3)$ & $144(38.6)$ & 0.001 \\
\hline Illness duration & $12.0 \pm 15.0$ & $10 \pm 18.2$ & 0.034 \\
\hline
\end{tabular}

${ }^{1}$ Missing information for 1 participant; ${ }^{2}$ Missing information for 3 participants; ${ }^{3}$ Missing information 16 participants; ${ }^{4}$ Missing information for 11 participants; ${ }^{5}$ Missing information for 3 participants; ${ }^{6}$ Missing information for 1 participant; ${ }^{7}$ Missing information for 7 participants; ${ }^{8}$ Excluding participants with COVID-19 symptoms before 6 March or after 31 March 2020. 
Table 5. Adjusted relative risks (aRR) of factors associated with an increase of anti-SARS-CoV-2 antibodies, considering the first and second SARS-CoV-2 serologic surveys, by Poisson regression. COVID-19 Borriana cohort 2020.

\begin{tabular}{|c|c|c|c|c|}
\hline Variables & aRR & $95 \% \mathrm{CI}^{1}$ & $p$-Value & Pearson Goodness of Fit \\
\hline Body mass index $\left(\mathrm{Kg} / \mathrm{m}^{2}\right)^{2}$ & 1.06 & $1.02-1.10$ & 0.001 & 0.996 \\
\hline Age (years) ${ }^{3}$ & 1.03 & $1.02-1.04$ & 0.000 & 0.991 \\
\hline Current smoker ${ }^{4}$ & 0.48 & $0.24-0.96$ & 0.037 & 0.997 \\
\hline Probable contact COVID-19 case $^{5}$ & 2.04 & $1.12-3.74$ & 0.022 & 0.994 \\
\hline Medical consultation ${ }^{6}$ & 1.62 & $1.12-2.34$ & 0.010 & 0.991 \\
\hline Illness duration ${ }^{7}$ & 0.99 & $0.99-1.01$ & 0.543 & 0.966 \\
\hline
\end{tabular}

${ }^{1} \mathrm{CI}=$ Confidence interval; ${ }^{2}$ Adjusted for age sex $\mathrm{ABO}$, occupation current smoker physical exercise alcohol consumption; ${ }^{3}$ Adjusted for sex $\mathrm{ABO} ;{ }^{4}$ Adjusted for age sex $\mathrm{ABO}$ occupation; ${ }^{5}$ Adjusted for age, sex $\mathrm{ABO}$ occupation current smoker physical exercise alcohol consumption assistance mass gathering events $\geq 2$ and over; ${ }^{6}$ Adjusted for age sex, ABO, chronic illness occupation; ${ }^{7}$ Adjusted by age sex, body mass index, $\mathrm{ABO}$, chronic illness.

Absolute difference in ECLIA arbitrary units between second and first serosurvey ECLIA titers evolution

COVID-19 Borriana cohort 2020
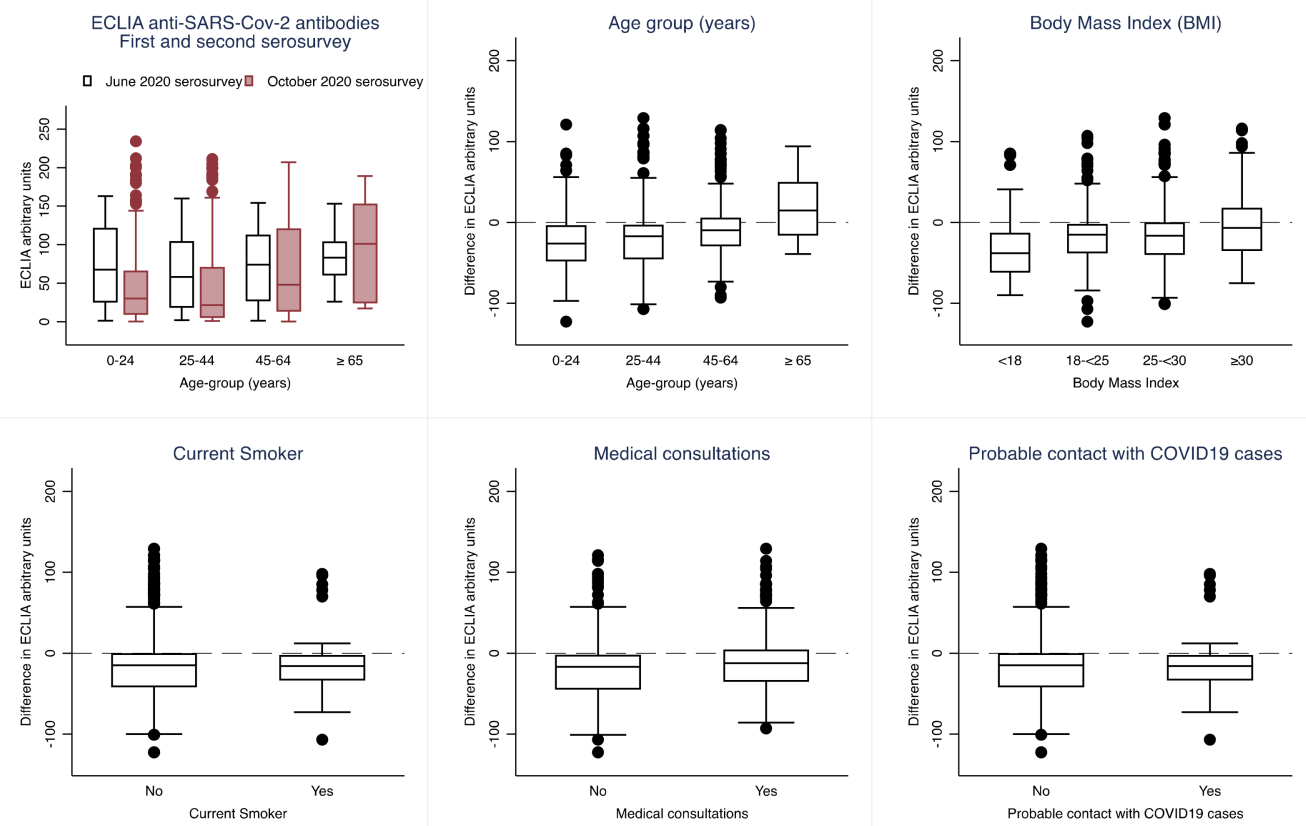

Figure 2. The absolute difference in ECLIA arbitrary units between second and first serosuvey. ECLIA titers evolution COVID-19 Borriana cohort 2020.

\section{Discussion}

Our results show that 99\% (479/484) of COVID-19 patients in the cohort maintained anti-SARS-CoV-2 antibodies in the first six months after the COVID-19 episode. We did not find evidence of any SARS-CoV-2 reinfection episode in this group in the period between the first and second serosurvey.

The factors associated with a negative result in the second serosurvey were a lower BMI, lower frequency of probable contact with COVID-19 cases, younger age and a milder COVID-19 episode when compared to the group with antibody persistence. Besides, we observed a significant overall decline in anti-SARS-CoV-2 antibodies. However, a fifth of participants showed an increase in anti-SARS-CoV-2 antibodies, which was probably related to the infection course or the frequency of contacts with other cases.

The persistence of anti-SARS-CoV-2 antibodies after the infection, measured by different serologic techniques, including ECLIA $[17,18]$ or other methods [19-22], has been reported to last between 4 and 8 months. However, significant differences in antibodies persistence associated with the detection techniques have been found, and total antibodies against $\mathrm{S} 1$ and the $\mathrm{S} 1$ receptor-binding domain (RBD) were detected for longer [23]. 
Several studies have described a similar decline of neutralising SARS-CoV-2 antibodies. This finding supports the need for follow-up studies to gather evidence on the duration of the antibody response and the protection against reinfections [24,25]. Although we did not observe reinfection episodes in our cohort, others have reported reinfection episodes. A $96 \%$ protective effectiveness in prior infected patients was estimated in care homes outbreaks $[26,27]$.

In the United States, and from data generated from commercial laboratory analysis of SARS-COV-2 antibody tests of 3.2 million patients, Harvey et al. found $0.30 \%$ reinfections [28]. In the United Kingdom, two cohort studies of health care workers comparing positive anti-SARS-COV-2 antibody group versus negative group during six months of follow-up [29], have found reinfection rate ratios of 0.11 and 0.16 , respectively [30]. In a vessel outbreak, three crew members with previous positive anti-SARS-COV-2 antibodies had not suffered infection versus 104 of 122 (85.2\%) crew members with negative antibodies, who suffered a SARS-CoV-2 infection $(p=0.002)$ [31].

A more severe COVID-19 disease is usually associated with higher anti-SARS-CoV-19 antibodies [32-34], and antibodies correlate with the duration of the infection, older age and hospitalisation [35,36]. Still, in other studies, age and symptoms were not associated with antibody levels [37], suggesting high variability. Also, high levels of anti-SARS-CoV IgG and neutralising antibodies were observed in COVID-19 patients with high BMI and patients with metabolic syndrome [33,38-40]. These results are in line with our finding, where low BMI was associated with negative antibodies. However, in obese COVID-19 patients, a reverse association has been observed between high BMI and lower SARS-CoV-2 antibodies [41]. In addition, the increase of SARS-CoV-2 antibodies in the second survey was associated with age older, higher BMI, more severe disease [42] and low current smoke. A hypothesis was suggested that a tobacco mosaic RNA virus, presented in the respiratory tract of smokers, could have some protection against the SARS-COV-2 virus [43]. However, the harmfulness of tobacco smoking in COVID-19 patients must be stressed in conjunction with continuing the research.

Factors indicating less exposure to COVID-19 cases in the group with negative antibodies suggest that the intensity, type and duration of exposure could play a role in developing the disease and its course [37,44,45]. Then, high viral load exposure with high duration may be decisive for the development and course of COVID-19 infection [46]. These results emphasised the crucial preventive measures to stop COVID-19 transmission: Keep distance, use masks, hand-washing and reduce time and contact of potential exposures.

The $\mathrm{O}$ ABO blood group was not associated with negative antibody groups, in line with the finding of Wendel et al. [38]. Still, the small sample of the negative antibody group prevents a definitive conclusion. Moreover, Vitamin D status was not related to the negative antibody group, but the measure as prevalence excludes a potential role [47]. On the other hand, negative antibodies were not associated with sex in contrast with Markmann et al.'s work [33], where men had more neutralising antibody levels than female.

Serologic surveys of SARS-CoV-2 infection are a useful approach in the control and prevention of COVID-19 disease, including the surveillance of the disease, to characterise the effectiveness of vaccinations against the disease, the antibody response relation to disease course, and the factors associated with the duration of the immune response [3].

Many serologic tests of SARS-CoV-2 measure IgA, IgG and IgM, with high heterogeneity in sensitivity and specificity [48]. The ECLIA technique has a good accuracy $[3,49,50]$ and has been recommended for population screening [51]. Anti-SARS-CoV-2 antibodies obtained by ECLIA positively correlate with neutralising antibodies, but their sensitivity should be improved [52,53].

Our study has some strengths; first, a prospective cohort design; second, the elevated participation rate; third, the use of a serologic test with reasonable sensitivity and specificity; four, the use of multivariate analysis to control potential confounding; fifth, a follow-up of up to 6 months; and finally, a population-based approach. 
As limitations, the quantitative ECLIA anti-SARS-CoV-2 antibodies test that we used has a significant, but feeble correlation (Pearson's correlation coefficient of 0.37 $p<0.001$ and poor linear relationship with the enzyme-linked immunosorbent assay (ELISA AESKULISA ${ }^{\mathrm{R}}$ ) [54]. The ECLIA test does not measure the response to the $\mathrm{S}$ antigen of SARS-CoV-2, but detects antibodies against the nucleocapsid $\mathrm{N}$. The non-simultaneous analysis of the blood samples from the two studies delimits the results, but only a qualitative approach, increase versus decline, was used.

Finally, the small number of participants with negative anti-SARS-CoV-2 antibodies decreases the power to detect associated factors; the younger age, and in general, milder COVID-19 disease of the cohort does not permit a generalisation of results, and we cannot discard the existence of unknown factors that we did not consider in this new disease.

In subsequent studies, a quantitative determination of neutralising antibodies against RDB antigen $[55,56]$ could be helpful to study the immunity against the SARS-CoV-2 virus considering the importance to define correlate levels of protective immunity $[57,58]$ and more precise estimation of potential factors associated with the clinical course $[59,60]$ As we can assume the future existence of vaccinated participants against SARS-CoV-2 in the cohort, the follow-up of the cohort would provide information on the response after vaccination against SARS-CoV-2 in patients who have suffered the infection [61] and inform the need of additional vaccine doses.

\section{Conclusions}

In the first six months after a COVID-19 infection, a high proportion of participants maintained detectable anti-SARS-CoV-2 antibodies, and we did not observe new COVID-19 episodes in the follow-up period.

Author Contributions: Conceptualization, S.D.-M., A.A.-P., M.R.P.-S., L.G.-L., D.J.-S., L.A.-E., U.C.A., S.F.-R., M.S.-U.; methodology, A.A.-P.,S.D.-M., J.P.-B., P.V.-U., M.L.-P., A.D.R.-G., S.F.-R., M.S.-U., G.F.-A., L.A.-E., G.B.-M., U.C.-A., C.D.-B., M.M.-B.; software A.A.-P., M.R.P.-S., J.P.-B.,M.C.L.-D.; validation, J.P.-B., C.N.-R. M.R.P.-S.; formal analysis, M.R.P.-S., A.A.-P., J.P.-B., S.D.-M.; investigation, S.D.-M., M.R.P.-S., P.V.-U., M.L.-P., A.D.R.-G., S.F.-R., G.F.-A., M.S.-U., L.A.-E., G.B.-M., B.C.-F., U.C.-A., C.D.-B., M.F.-C., L.G.-L., D.J.-S., M.C.L.-D., M.D.L.-V., M.M.-B., C.N.-R., R.R.-P., S.V.-L.; resources, S.D.-M., G.F.-A., G.B.-M., B.C.-F., M.F.-C., L.G.-L., M.C.L.-D., M.D.L.-V., M.L.-P., C.N.-R., R.R.-P., S.V.-L.; data curation, A.A.-P., J.P.-B., P.V.-U., M.L.-P., A.D.R.-G., M.R.P.-S.; writing original draft preparation, A.A.-P., J.P.-B., M.R.P.-S., M.C.L.-D., S.D.-M., S.F.-R.; writing-review and editing, J.P.-B., A.A.-P., S.D.-M., U.C.-A., M.F.-C., M.C.L.-D.; visualization, J.P.-B., D.J.-S., L.A.-E., L.G.-L.; supervisión M.R.P.-S., M.C.L.-D.; project admistration, S.D.-M., A.A.-P., M.C.L.-D., G.F.-A.; funding acquision, S.D.-M., M.C.L.-D., A.A.-P. All authors have read and agreed to the published version of the manuscript.

Funding: This research received no external funding.

Institutional Review Board Statement: The study was conducted according to the guidelines of the Declaration of Helsinki, and the study of this cohort was a part of the public health surveillance as a prolongation of the COVID-19 outbreak in the Falles festival of Borriana control measures [62], and was exempt from the Ethics Review Board approval's protocol according to the Spanish legislation, including the General Low including the General Law of Health [63], the Law of Cohesion and Quality of the National System of Health [64], and the Law General of Public Health [65]. In addition, the cohort was followed to respond to a new disease, the COVID-19 pandemic [66].

Informed Consent Statement: Informated consent was obtained from all subject involved in the study.

Data Availability Statement: Data of the this study can be consulted if the authors are requested. Dataset: borrianacohort.dta.

Acknowledgments: We thank the participants of the cohort and the Borriana's Falles organisation for the support that made it possible to perform this study. In addition, we appreciate the assistance and support of Roser Blasco-Gari, Helena Buj-Jorda, Israel Borras-Acosta, Lucia Castell-Agusti, Mercedes De Francia-Valero, Maria Domènech-Molinos, Marc Garcia, Maria Gil-Fortuño, Elena Grañana-Toran, Noelia Hernández-Perez, Laura Lopez-Diago, Salvador Martinez-Parra, Sara Moner-Marin, Silvia 
Pesudo-Calatayud, Lara Sabater-Hernández, Maria Luisa Salve-Martinez, Irene Suarez-Linares, Juan José Ventura-Buchardo, and Alberto Yagüe-Muñoz to carry out the study.

Conflicts of Interest: The authors declare no conflict of interest.

\section{References}

1. Johns Hopkins University. COVID-19 Data in Motion: 12 May 2021. Available online: https://coronavirus.jhu.edu/ (accessed on 12 May 2021).

2. Clapham, H.; Hay, J.; Routledge, I.; Takahashi, S.; Choisy, M.; Cummings, D.; Grenfell, B.; Metcalf, C.J.E.; Mina, M.; Barraquer, I.R.; et al. Seroepidemiologic study designs for determining SARS-COV-2 transmission and immunity. Emerg. Infect. Dis. 2020, 26, 1978-1986. [CrossRef] [PubMed]

3. Lee, C.Y.; Lin, R.T.P.; Renia, L.; Ng, L.F.P. Serological approaches for COVID-19: Epidemiologic perspective on surveillance and control. Front. Immunol. 2020, 11, 879. [CrossRef] [PubMed]

4. Sette, A.; Crotty, S. Adaptive immunity to SARS-CoV-2 and COVID-19. Cell 2021, 184, 861-880. [CrossRef] [PubMed]

5. Hanna, S.J.; Codd, A.S.; Gea-Mallorqui, E.; Scourfield, D.O.; Richter, F.C.; Ladell, K.; Borsa, M.; Compeer, E.B.; Moon, O.R.; Galloway, S.A.E.; et al. T cell phenotypes in COVID-19-a living review. Oxf. Open Immunol. 2020, 2, iqaa007. [CrossRef]

6. $\quad$ Egger, M.; Bundschuh, C.; Wiesinger, K.; Gabriel, C.; Clodi, M.; Mueller, T.; Dieplinger, B. Comparison of the Elecsys ${ }^{\circledR}$ Anti-SARSCoV-2 immunoassay with the EDI ${ }^{\mathrm{TM}}$ enzyme linked immunosorbent assays for the detection of SARS-CoV-2 antibodies in human plasma. Clin. Chim. Acta 2020, 509, 18-21. [CrossRef]

7. Dellière, S.; Salmona, M.; Minier, M.; Gabassi, A.; Alanio, A.; Le Goff, J.; Delaugerre, C.; Chaix, M.L.; Saint-Louis CORE (COvid REsearch) group. Evaluation of the COVID-19 IgG/IgM rapid test from Orient Gene Biotech. J. Clin. Microbiol. 2020, 58, e01233-20. [CrossRef]

8. Yip, C.C.; Sridhar, S.; Cheng, A.K.; Leung, K.H.; Choi, G.K.; Chen, J.H.; Poon, R.W.; Chan, K.H.; Wu, A.K.; Chan, H.S.; et al Evaluation of the commercially available LightMix ${ }^{\circledR}$ Modular E-gene kit using clinical and proficiency testing specimens for SARS-CoV-2 detection. J. Clin. Virol. 2020, 129, 104476. [CrossRef]

9. Fan, Q.; Zhang, W.; Li, B.; Li, D.J.; Zhang, J.; Zhao, F. Association between ABO Blood Group System and COVID-19 susceptibility in Wuhan. Front. Cell. Infect. Microbiol. 2020, 10, 404. [CrossRef]

10. Wu, Y.; Feng, Z.; Li, P.; Yu, Q. Relationship between ABO blood group distribution and clinical characteristics in patients with COVID-19. Clin. Chim. Acta 2020, 509, 220-223. [CrossRef]

11. Merzon, E.; Tworowski, D.; Gorohovski, A.; Vinker, S.; Golan Cohen, A.; Green, I.; Frenkel-Morgenstern, M. Low plasma 25(OH) vitamin D level is associated with increased risk of COVID-19 infection: An Israeli population-based study. FEBS J. 2020, 287, 3693-3702. [CrossRef]

12. Kaufman, H.W.; Niles, J.K.; Kroll, M.H.; Bi, C.; Holick, M.F. SARS-CoV-2 positivity rates associated with circulating 25hydroxyvitamin D levels. PLoS ONE 2020, 15, e0239252. [CrossRef]

13. Lapierre, Y.; Rigal, D.; Adam, J.; Josef, D.; Meyer, F.; Greber, S.; Drot, C. The gel test: A new way to detect red cell antigen-antibody reactions. Transfusion 1990, 30, 109-113. [CrossRef]

14. Asif, M.; Groboske, S.E.; Leung, E.K.Y.; Yeo, K.J.; van Wijk, X.M.R. Evaluation of a new generation automated assay for 25-hydroxy vitamin D based on competitive protein binding. J. Appl. Lab. Med. 2019, 4, 247-253. [CrossRef]

15. Greenland, S.; Pearl, J.; Robins, J.M. Causal diagrams for epidemiologic research. Epidemiology 1999, 10, 37-48. [CrossRef]

16. Textor, J.; van der Zander, B.; Gilthorpe, M.S.; Liskiewicz, M.; Ellison, G.T. Robust causal inference using directed acyclic graphs: The R package 'dagitty'. Int. J. Epidemiol. 2016, 45, 1887-1894. [CrossRef]

17. Fejt, V.; Krátká, Z.; Zelená, H.; Fürst, T. Age is not a disease: Evolution of protective antibodies against SARS-CoV-2 in seniors from the Břevnice nursing home. Cas. Lek. Cesk. 2020, 159, 303-311.

18. Choe, P.G.; Kim, K.H.; Kang, C.K.; Suh, H.J.; Kang, E.; Lee, S.Y.; Kim, N.J.; Yi, J.; Park, W.B.; Oh, M.D. Antibody responses 8 months after asymptomatic or mild SARS-CoV-2 infection. Emerg. Infect. Dis. 2021, 27, 928-931. [CrossRef]

19. Wajnberg, A.; Amanat, F.; Firpo, A.; Altman, D.R.; Bailey, M.J.; Mansour, M.; McMahon, M.; Meade, P.; Mendu, D.R.; Muellers, K.; et al. Robust neutralizing antibodies to SARS-CoV-2 infection persist for months. Science 2020, 370, 1227-1230. [CrossRef]

20. Gudbjartsson, D.F.; Norddahl, G.L.; Melsted, P.; Gunnarsdottir, K.; Holm, H.; Eythorsson, E.; Arnthorsson, A.O.; Helgason, D.; Bjarnadottir, K.; Ingvarsson, R.F.; et al. Humoral immune response to SARS-CoV-2 in Iceland. N. Engl. J. Med. 2020, 383, 1724-1734. [CrossRef]

21. Ripperger, T.J.; Uhrlaub, J.L.; Watanabe, M.; Wong, R.; Castaneda, Y.; Pizzato, H.A.; Thompson, M.R.; Bradshaw, C.; Weinkauf, C.C.; Bime, C.; et al. Orthogonal SARS-CoV-2 serological assays enable surveillance of low-prevalence communities and reveal durable humoral immunity. Immunity 2020, 53, 925-933.e4. [CrossRef]

22. Dan, J.M.; Mateus, J.; Kato, Y.; Hastie, K.M.; Yu, E.D.; Faliti, C.E.; Grifoni, A.; Ramirez, S.I.; Haupt, S.; Frazier, A.; et al. Immunological memory to SARS-CoV-2 assessed for up to 8 months after infection. Science 2021, 371, eabf4063. [CrossRef]

23. Favresse, J.; Eucher, C.; Elsen, M.; Gillot, C.; Van Eeckhoudt, S.; Dogné, J.M.; Douxfils, J. Persistence of anti-SARS-CoV-2 antibodies depends on the analytical kit: A report for up to 10 months after infection. Microorganisms 2021, 9, 556. [CrossRef] [PubMed]

24. Nguyen-Contant, P.; Embong, A.K.; Kanagaiah, P.; Chaves, F.A.; Yang, H.; Branche, A.R.; Topham, D.J.; Sangster, M.Y. S ProteinReactive IgG and memory B cell production after human SARS-CoV-2 infection includes broad reactivity to the S2 subunit. $m B i o$ 2020, 11, e01991-20. [CrossRef] [PubMed] 
25. Seow, J.; Graham, C.; Merrick, B.; Acors, S.; Pickering, S.; Steel, K.J.A.; Hemmings, O.; O’Byrne, A.; Kouphou, N.; Galao, R.P.; et al. Longitudinal observation and decline of neutralizing antibody responses in the three months following SARS-CoV-2 infection in humans. Nat. Microbiol. 2020, 5, 1598-1607. [CrossRef] [PubMed]

26. West, J.; Everden, S.; Nikitas, N. A case of COVID-19 re-infection in the UK. Clin. Med. 2021, 21, e52-e53. [CrossRef] [PubMed]

27. Jeffery-Smith, A.; Iyanger, N.; Williams, S.V.; Chow, J.Y.; Aiano, F.; Hoschler, K.; Lackenby, A.; Ellis, J.; Platt, S.; Miah, S.; et al. Antibodies to SARS-CoV-2 protect against re-infection during outbreaks in care homes, September and October 2020. Eurosurveillance 2021, 26, 2100092. [CrossRef]

28. Harvey, R.A.; Rassen, J.A.; Kabelac, C.A.; Turenne, W.; Leonard, S.; Klesh, R.; Meyer, W.A., III; Kaufman, H.W.; Anderson, S.; Cohen, O.; et al. Association of SARS-CoV-2 seropositive antibody test with risk of future infection. JAMA Intern. Med. 2021, 181, 672-679. [CrossRef] [PubMed]

29. Lumley, S.F.; O'Donnell, D.; Stoesser, N.E.; Matthews, P.C.; Howarth, A.; Hatch, S.B.; Marsden, B.D.; Cox, S.; James, T.; Warren, F.; et al. Antibody status and incidence of SARS-CoV-2 infection in health care workers. N. Engl. J. Med. 2021, 384, 533-540. [CrossRef]

30. Hall, V.J.; Foulkes, S.; Charlett, A.; Atti, A.; Monk, E.J.M.; Simmons, R.; Wellington, E.; Cole, M.J.; Saei, A.; Oguti, B.; et al. SARS-CoV-2 infection rates of antibody-positive compared with antibody-negative health-care workers in England: A large, multicentre, prospective cohort study (SIREN). Lancet 2021, 397, 1459-1469. [CrossRef]

31. Addetia, A.; Crawford, K.H.D.; Dingens, A.; Zhu, H.; Roychoudhury, P.; Huang, M.L.; Jerome, K.R.; Bloom, J.D.; Greninger, A.L. Neutralizing antibodies correlate with protection from SARS-CoV-2 in humans during a fishery vessel outbreak with a high attack rate. J. Clin. Microbiol. 2020, 58, e02107-20. [CrossRef]

32. Zhao, J.; Yuan, Q.; Wang, H.; Liu, W.; Liao, X.; Su, Y.; Wang, X.; Yuan, J.; Li, T.; Li, J.; et al. Antibody responses to SARS-CoV-2 in patients with novel coronavirus disease 2019. Clin. Infect. Dis. 2020, 71, 2027-2034. [CrossRef]

33. Markmann, A.J.; Giallourou, N.; Bhowmik, D.R.; Hou, Y.J.; Lerner, A.; Martinez, D.R.; Premkumar, L.; Root, H.; van Duin, D.; Napravnik, S.; et al. Sex disparities and neutralizing antibody durability to SARS-CoV-2 infection in convalescent individuals. medRxiv 2021, 3. [CrossRef]

34. Zhang, X.; Lu, S.; Li, H.; Wang, Y.; Lu, Z.; Liu, Z.; Lai, Q.; Ji, Y.; Huang, X.; Li, Y.; et al. Viral and antibody kinetics of COVID-19 patients with different disease severities in acute and convalescent phases: A 6-month follow-up study. Virol. Sin. 2020, 35, 820-829. [CrossRef]

35. Benner, S.E.; Patel, E.U.; Laeyendecker, O.; Pekosz, A.; Littlefield, K.; Eby, Y.; Fernandez, R.E.; Miller, J.; Kirby, C.S.; Keruly, M.; et al. SARS-CoV-2 antibody avidity responses in COVID-19 patients and convalescent plasma donors. J. Infect. Dis. 2020, 222, 1974-1984. [CrossRef]

36. Shields, A.M.; Faustini, S.E.; Perez-Toledo, M.; Jossi, S.; Allen, J.D.; Al-Taei, S.; Backhouse, C.; Dunbar, L.; Ebanks, D.; Emmanuel, B.; et al. Serological responses to SARS-CoV-2 following non-hospitalised infection: Clinical and ethnodemographic features associated with the magnitude of the antibody response. medRxiv 2020, 16. [CrossRef]

37. Ladhani, S.N.; Jeffery-Smith, A.; Patel, M.; Janarthanan, R.; Fok, J.; Crawley-Boevey, E.; Vusirikala, A.; De Olano, E.F.; Perez, M.S.; Tang, S.; et al. High prevalence of SARS-CoV-2 antibodies in care homes affected by COVID-19: Prospective cohort study, England. EClinicalMedicine 2020, 28, 100597. [CrossRef]

38. Wendel, S.; Fontão-Wendel, R.; Fachini, R.; Candelaria, G.; Scuracchio, P.; Achkar, R.; Brito, M.; Reis, L.F.; Camargo, A.; Amano, M.; et al. A longitudinal study of convalescent plasma (CCP) donors and correlation of ABO group, initial neutralizing antibodies $(\mathrm{nAb})$, and body mass index (BMI) with $\mathrm{nAb}$ and anti-nucleocapsid (NP) SARS-CoV-2 antibody kinetics: Proposals for better quality of CCP collections. Transfusion 2021, 61, 1447-1460. [CrossRef]

39. Racine-Brzostek, S.E.; Yang, H.S.; Jack, G.A.; Chen, Z.; Chadburn, A.; Ketas, T.J.; Francomano, E.; Klasse, P.J.; Moore, J.P.; McDonough, K.A.; et al. Postconvalescent SARS-CoV-2 IgG and neutralizing antibodies are elevated in individuals with poor metabolic health. J. Clin. Endocrinol. Metab. 2021, 106, e2025-e2034. [CrossRef]

40. Gerhards, C.; Thiaucourt, M.; Kittel, M.; Becker, C.; Ast, V.; Hetjens, M.; Neumaier, M.; Haselmann, V. Longitudinal assessment of anti-SARS-CoV-2 antibody dynamics and clinical features following convalescent from COVID-19 infection. Int. J. Infect. Dis. 2021, 28. [CrossRef]

41. Frasca, D.; Reidy, L.; Cray, C.; Diaz, A.; Romero, M.; Kahl, K.; Blomberg, B.B. Influence of obesity on serum levels of SARS-CoV-2specific antibodies in COVID-19 patients. PLoS ONE 2021, 16, e0245424. [CrossRef]

42. De Giorgi, V.; West, K.A.; Henning, A.N.; Chen, L.; Holbrook, M.R.; Gross, R.; Liang, J.; Postnikova, E.; Trenbeath, J.; Pogue, S.; et al. Anti-SARS-CoV-2 Serology persistence over time in COVID-19 Convalescent Plasma Donors. medRxiv 2021, 10. [CrossRef]

43. de Bernardis, E.; Busà, L. A putative role for the tobacco mosaic virus in smokers' resistance to COVID-19. Med. Hypotheses 2020, 143, 110153. [CrossRef]

44. Matricardi, P.M.; Dal Negro, R.W.; Nisini, R. The first, holistic immunological model of COVID-19: Implications for prevention, diagnosis, and public health measures. Pediatr. Allergy Immunol. 2020, 31, 454-470. [CrossRef]

45. Iwuji, K.; Islam, E.; Berdine, G.; Nugent, K.; Test, V.; Tijerina, A. Prevalence of coronavirus antibody among first responders in Lubbock, Texas. J. Prim. Care Community Health 2020, 11, 2150132720971390. [CrossRef] [PubMed]

46. Calisti, R. SARS-CoV-2: Exposure to high external doses as determinants of higher viral loads and of increased risk for COVID-19. A systematic review of the literature. Epidemiol. Prev. 2020, 44, 152-159. [CrossRef] [PubMed] 
47. Barassi, A.; Pezzilli, R.; Mondoni, M.; Rinaldo, R.F.; DavĪ, M.; Cozzolino, M.; Melzi D’Eril, G.V.; Centanni, S. Vitamin D in severe acute respiratory syndrome coronavirus 2 (SARS-CoV-2) patients with non-invasive ventilation support. Panminerva Med. 2021, 25. [CrossRef]

48. Deeks, J.J.; Dinnes, J.; Takwoingi, Y.; Davenport, C.; Spijker, R.; Taylor-Phillips, S.; Adriano, A.; Beese, S.; Dretzke, J.; di Ruffano, L.F.; et al. Antibody tests for identification of current and past infection with SARS-CoV-2. Cochrane Database Syst. Rev. 2020, 6, CD013652. [CrossRef]

49. Afzal, N.; Tariq, N.; Raza, S.; Shakeel, D. Diagnostic accuracy of electro-chemiluminescence immunoassay anti-SARS-CoV-2 serological test. Cureus 2021, 13, e12588. [CrossRef]

50. Kittel, M.; Findeisen, P.; Muth, M.C.; Thiaucourt, M.; Gerhards, C.; Neumaier, M.; Haselmann, V. Specificity testing by point prevalence as a simple assessment strategy using the Roche Elecsys ${ }^{\circledR}$ anti-SARS-CoV-2 immunoassay. Int. J. Infect. Dis. 2021, 105, 632-638. [CrossRef]

51. Speletas, M.; Kyritsi, M.A.; Vontas, A.; Theodoridou, A.; Chrysanthidis, T.; Hatzianastasiou, S.; Petinaki, E.; Hadjichristodoulou, C. Evaluation of two chemiluminescent and three ELISA immunoassays for the detection of SARS-CoV-2 IgG antibodies: Implications for disease diagnosis and patients' management. Front. Immunol. 2020, 11, 609242. [CrossRef]

52. Kohmer, N.; Westhaus, S.; Rühl, C.; Ciesek, S.; Rabenau, H.F. Brief clinical evaluation of six high-throughput SARS-CoV-2 IgG antibody assays. J. Clin. Virol. 2020, 129, 104480. [CrossRef]

53. Müller, L.; Ostermann, P.N.; Walker, A.; Wienemann, T.; Mertens, A.; Adams, O.; Andree, M.; Hauka, S.; Lübke, N.; Keitel, V.; et al. Sensitivity of anti-SARS-CoV-2 serological assays in a high-prevalence setting. Eur. J. Clin. Microbiol. Infect. Dis. 2021, 40, 1063-1071. [CrossRef]

54. Khawaja, S.; Asif, M.; Naz Mukry, S.; Sultan Shamsi, T. Possible correlation of electrochemiluminescence based numerical cut off index value with concentration of anti-SARS-CoV-2 antibody: Is it worth reporting? J. Public Health Res. 2021, 10, 2079. [CrossRef]

55. Peterhoff, D.; Glück, V.; Vogel, M.; Schuster, P.; Schütz, A.; Neubert, P.; Albert, V.; Frisch, S.; Kiessling, M.; Pervan, P.; et al. A highly specific and sensitive serological assay detects SARS-CoV-2 antibody levels in COVID-19 patients that correlate with neutralization. Infection 2021, 49, 75-82. [CrossRef]

56. Figueiredo-Campos, P.; Blankenhaus, B.; Mota, C.; Gomes, A.; Serrano, M.; Ariotti, S.; Costa, C.; Nunes-Cabaço, H.; Mendes, A.M.; Gaspar, P.; et al. Seroprevalence of anti-SARS-CoV-2 antibodies in COVID-19 patients and healthy volunteers up to 6 months post disease onset. Eur. J. Immunol. 2020, 50, 2025-2040. [CrossRef]

57. Krammer, F. Correlates of protection from SARS-CoV-2 infection. Lancet 2021, 397, 1421-1423. [CrossRef]

58. Furukawa, K.; Arii, J.; Nishimura, M.; Tjan, L.H.; Lystia Poetranto, A.; Ren, Z.; Aktar, S.; Huang, J.R.; Sutandhio, S.; Kurahashi, Y.; et al. Seroepidemiological survey of the antibody for severe acute respiratory syndrome coronavirus 2 with neutralizing activity at hospitals: A cross-sectional study in Hyogo Prefecture, Japan. JMA J. 2021, 4, 41-49. [CrossRef]

59. Schaffner, A.; Risch, L.; Aeschbacher, S.; Risch, C.; Weber, M.C.; Thiel, S.L.; Jüngert, K.; Pichler, M.; Grossmann, K.; Wohlwend, N.; et al. Characterization of a pan-immunoglobulin assay quantifying antibodies directed against the receptor binding domain of the SARS-CoV-2 S1-Subunit of the spike protein: A population-based study. J. Clin. Med. 2020, 9, 3989. [CrossRef]

60. Anichini, G.; Terrosi, C.; Gandolfo, C.; Gori Savellini, G.; Fabrizi, S.; Miceli, G.B.; Cusi, M.G. SARS-CoV-2 Antibody Response in Persons with Past Natural Infection. N. Engl. J. Med. 2021. [CrossRef]

61. Saadat, S.; Tehrani, Z.R.; Logue, J.; Newman, M.; Frieman, M.B.; Harris, A.D.; Sajadi, M.M. Binding and Neutralization Antibody Titers After a Single Vaccine Dose in Health Care Workers Previously Infected With SARS-CoV-2. JAMA 2021, 325, 1467-1469. [CrossRef]

62. Domènech-Montoliu, S.; Pac-Sa, M.R.; Vidal-Utrillas, P.; Latorre-Poveda, M.; Del Rio-González, A.; Ferrando-Rubert, S.; FerrerAbad, G.; Sánchez-Urbano, M.; Aparisi-Esteve, L.; Badenes-Marques, G.; et al. Mass gathering events and COVID-19 transmission in Borriana (Spain): A retrospective cohort study. PLOS ONE 2021, 16, e0256747. [CrossRef]

63. Ley 14/1986, de 25 de abril, General de Sanidad (Law General of Health). Available online: https://www.boe.es/eli/es/1/1986 /04/25/14/con (accessed on 2 August 2021).

64. Ley 16/2003, de 28 de mayo, de cohesión y calidad del Sistema Nacional de Salud. (Law of Cohesion and Quality of the National System of Health). Available online: https:/ / www.boe.es/eli/es/1/2003/05/28/16 (accessed on 2 August 2021).

65. Ley 33/2011, de 4 de octubre, General de Salud Pública (Law General of Public Health). Available online: https: / www.boe.es / eli/es/1/2011/10/04/33/con (accessed on 2 August 2021).

66. Ministerio de Sanidad Acordado en Consejo Interterritorial del Sistema Nacional de Salud el 16 de julio de 2020. Plan de respuesta temprana en un escenario de control de la pandemia por el COVID-19.pdf (Ministry of Health Agreed in the Interterritorial Council of the National Health System on July 16, 2020". Early response plan in a COVID-19 pandemic control scenario.pdf). Available online: https://www.mscbs.gob.es/profesional/saludPublica/alertasActual/nCOV/documetos/CoVID19_Plan_de_ respuesta_temprana_escenario_control.pdf (accessed on 2 August 2021). 